\title{
Çevresel Gelişme Sürecinde Yüksek Kaldırım
}

Arş. Gör. Pınar Arabacıoğlu

Y.T.Ü. Mimarlık Fakültesi, Mimarlık Bölümü,

Bina Bilgisi Ana Bilim Dalı, Çevre Düzenleme Bilim Dalı

\section{Giriş}

Uluslararası kültür, siyaset, turizm ve ticaret merkezlerinden biri olan İstanbul, bugün hızla büyüyen nüfusu, çözümlenmeyi bekleyen sorunlarıyla problemli bir kent konumundadır. Eşsiz niteliklere sahip bu kentin üzerine günümüzde plansız, programsız yapılar inşa edilmekte, şehrin görüntüsü gün geçtikçe tanınmaz hale gelmektedir (Resim: 1). İstanbul'un geçmişini, kültürünü yansıtan tarihsel yapı ve kentsel dokuları, bir yandan uzun süre kullanılmamanın veya işlevsel eskimenin etkisiyle ciddi sorunlar yaşarken, öte yandan yanlış uygulamalar sonucu sahip oldukları kültürel değerleri yitirmek tehlikesiyle karşı karşıyadır. İstanbul'un en eski yerleşim bölgelerinden

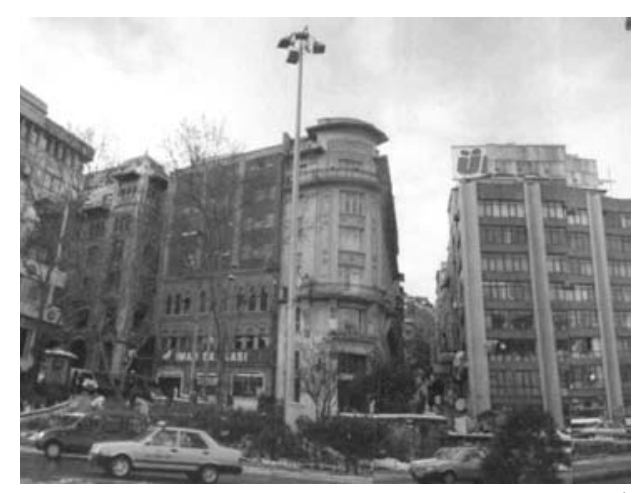

94 Sayı 4, Mayıs 2006 biri olan ve bu sosyal değişimi yansitan Galata-Yüksek Kaldırım bu çalışmanın ana konusudur (Resim: 2).

\section{Bölgenin Genel Tarihi}

İstanbul'un Batı ile tüm ticaret ilişkilerinin kurulduğu ve yürütüldüğü bölge olan Galata, fetihten sonra da yabancıların yaşadığı bir liman olma özelliğini korumuştur.

\subsection{Antik Çağlar}

Tarihin başı olarak sayılan, yazılı tarihin başlangıç dönemlerine ait bölge ile ilgili bilgiler, bölgenin Balkanlar ve Avrupa ile Anadolu ve Asya arasında doğal bir köprü olduğundan ve yoğun bir insan trafiğini barınmasından öteye gidememektedir. Tarih boyunca bölge önemli konumu

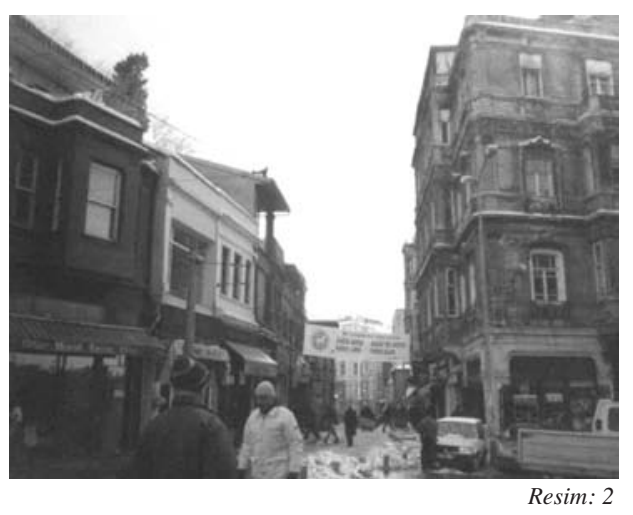

Özet:

Dünyada benzersiz bir kültür mozaiğine sahip olan İstanbul, günümüzde nüfus artışı, kırsal alanlardan kente göç gibi nedenlerle büyük bir değișim içerisindedir. Bu yazının amacı bu değişimi karakteristik bir biçimde yansitan alanlardan biri olan GalataYüksek Kaldırım bölgesinin geçmişi ve bugünü arasındaki sosyal çevre farklılıklarını ve bu sosyal değiş̧imi nedenleri ve sonuçları ile irdelemektir. $\mathrm{Bu}$ makalede, öncelikle Yüksek Kaldırım'ın yapısının analiz edilebilmesi için Galata'nın genel tarihine değinilmektedir. Bu bilgiler Yüksek Kaldırım'ın sosyal ve fiziksel yapısının geçmişten günümüze kadar geçirdiği gelişimin saptanmasını sağlamaktadır. Daha sonra, Türk yazınında Yüksek Kaldırım'a dair anlatılanlara örnekler sunulmakta, bölgenin tarihin çeşitli dönemlerindeki yüzü, orada yaşayan insan profili anlatılmaktadır. Bu bilgilerin ışı̆̆ında da Yüksek Kaldırım'ın günümüzdeki durumu ve problemleri değerlendirilmektedir.

summary:

The city of Istanbul, which has a unique cultural mosaic, is in an evolution progress, as a result of problems as the high population growth and immigration from rural areas to the city. The aim of this research is to examine the environmental differences and the social changes between the past and the present in the Galata-Yüksek Kaldırım quarter, which is reflecting these characteristic changes. The article starts with the general history of the Galata quarter which helps to analyze and determine the social and physical condition and the evolution of the quarter. Afterwards some examples of the Turkish literature are being presented, which are explaining the area's face, and the profile of people living there, in certain periods. In the light of this information, the condition and the problems of today are being discussed. Anahtar kelimeler:

Çevre, Mekan, Yüksek Kaldırım, Sosyal

Değişim Keywords: Environment, Space, Yüksek Kaldırım, Social Evolution 
Resim: I

yüksek Kaldırım'ın

Karaköy Girişi

Resim: 2

yüksek Kaldırım'ın

Beyoğlu Girişi

Resim: 3

Antik Çă̆da Galata

(Müller-Wiener, 1998)

Resim: 4

4-7. Yüzyıllarda Galata

(Müller-Wiener, 1998)

Resim: 5

8-12. Yüzyıllarda

Galata

(Müller-Wiener, 1998)

Resim: 6

13-15. Yüzyıllarda

Galata (Müller-Wiener, 1998)

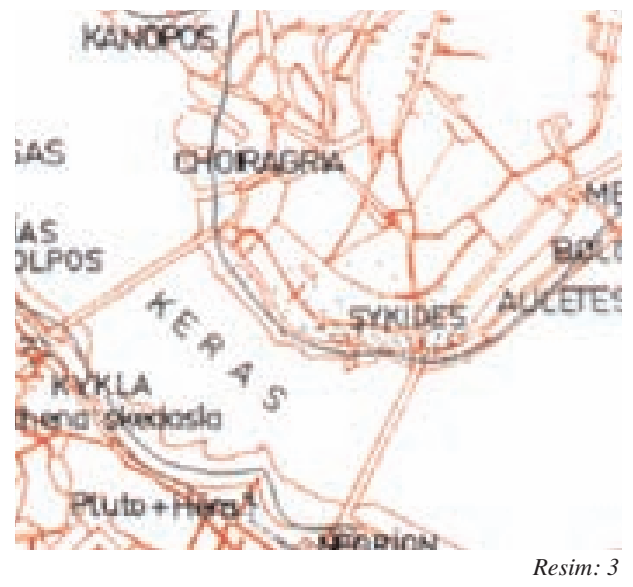

nedeniyle birçok devlet tarafından istilaya uğramıştır (Müller-Wiener 1998, 82-84), (Resim: 3).

\subsection{4-7. Yüzyıllar}

I. Constantin'in döneminden itibaren sur duvarlariyla korunan bir Galata'dan bahsetmek mümkündür (Eyice, 1994). II.

Constantin ise bölgeyi sınırlar içine alarak "Regio Sycaena" adını vermiş ve "vici" denilen mahallelere ayırmıştır. 6 . yüzyılda Haliç'e girişin kontrol edilmesi zorunluluğu, 7. yüzyılda Bizans, Sasanlar ve Avarların yanı sıra Müslüman Arapların da saldırıları, taht kavgaları ve ayaklanmalar ile birlikte bölge her dönemde karışıklıklara sahne olmuştur (Müller-Wiener 1998, 82-84) (Resim: 4).

\subsection{8-12. Yüzyıllar}

Cenevizlilerin İstanbul'a yerleşmeleri 12. yüzyıla rastlar. Bu dönemde Galata'da Venedikliler ve Pisalılar da yaşamaktadır (Eyice, 1994).
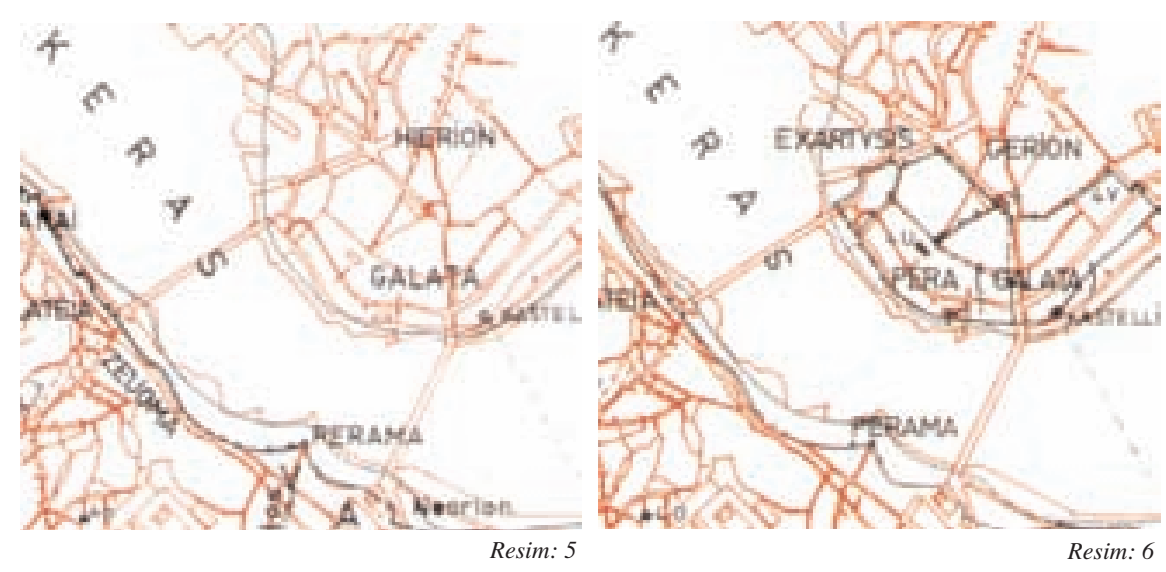

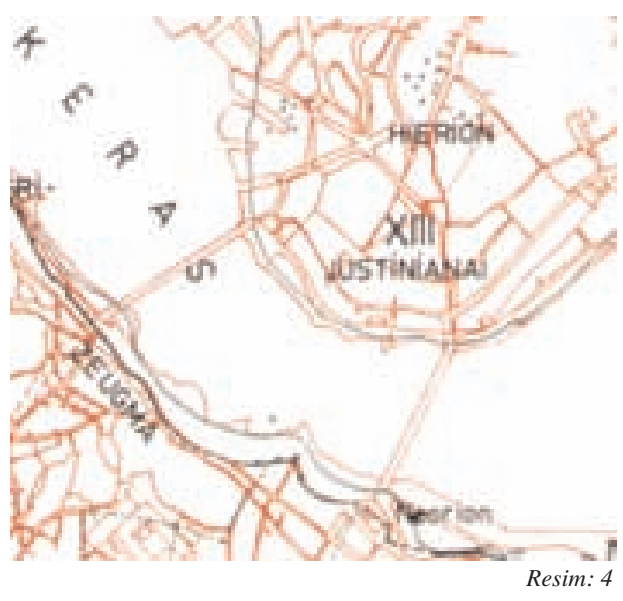

Çok kalabalık olan Cenevizlilere büyük bir bölge tahsis edilmiş, özellikle 13. yüzyılda İstanbul'un Latinlerden geri alınması ile Cenevizliler Bizanslılardan çok özel haklar elde etmişlerdir (Eyice, 1994). Cenevizliler dönem dönem İmparatorluğun zayıflığından yararlanarak bölgeyi surlarla çevirmişlerdir (MüllerWiener 1998, 84-86). (Resim: 5).

\subsection{3-15. Yüzyıllar}

Bizanslılar zayıfladıkça Cenova kolonisi kuvvetlenmiş, ticaret ve gümrükten elde ettiği kazanç onu günden güne zenginleştirmiştir. Bir taraftan da bölgenin sınırlarını genişletmişlerdir (Eyice 1969, 49). İstanbul Osmanlıların eline geçtiğinde ise Galata yöneticileri ile yapılan anlaşmaya göre Bizans döneminden beri Cenevizlilerin sahibi oldukları imtiyazların bir kısmı korunmuş ancak bölgeye hakimiyetleri reddedilmiştir (Müller-Wiener 1998, 84-86). "Bizans ve Ceneviz döneminde gelişmesi sur içi bölge ile sınırlı kalan Galata, buradaki Ceneviz kolonisinin etkisiyle tam bir İtalyan şehri görünümü içinde gelişmiş, bina ve sokakları Akdeniz şehirlerindeki benzerleri gibi yapılmıştı. Arazinin dik eğimli oluşu nedeniyle sokakların bir kısmı merdivenli olarak inşa edilmişti."(Eyice, 1994) (Resim: 6). 
Bu dönemde Galata hala çok sayıda ticari geminin uğrak yeri olan işlek bir liman kentidir. 15. yüzyılın ilk yarısında Akdeniz'de bulunan Marsilya, Venedik, Cenova gibi diğer liman kentlerindekine eşdeğer gemi bakım ve tamir atölyelerine sahiptir. Aynı dönemde bölgede kilise ve benzeri yapıların inşası sınırlandırılmış, bölgeye İzmirli Rumlar, Tophane'ye de Sinop ve Samsun'dan gelenler yerleştirilmiştir. Aynı yüzyıldan itibaren Cenevizlilerin Galata'daki etkinliği gittikçe azalmaya başlamıştır (Arkan, 1988). $\mathrm{Bu}$ dönemde Galata özel durumunu koruyan bir ticaret merkezi haline gelmiştir. Bölgedeki liman nedeniyle yabancı nüfusun yoğun olması bölgenin, İstanbul'un başka hiçbir yerinde bulunmayan sayıda meyhaneye ev sahipliği yapmasına sebep olmuştur (Belge, 1999).

\subsection{Yüzyıl Sonrası}

17. yüzyılda Kanunî’nin Fransızlara tanıdı $\breve{g} 1$ kapitülasyonların sonucunda Galata'da ticaret hareketlenmiş, bölge Akdeniz'deki en önemli liman kentlerinden biri haline gelmiştir. Bu da konut alanlarının Pera'ya, oradan da Taksim bölgesine doğru kaymasına neden olmuştur. Eğimin çok fazla, yolların son derece dar ve kıyıdaki liman kuruluşlarına ticaretin yakın olması ile ticaret Pera'ya doğru genişleyememiş, kıyı bölgesindeki konut alanları ticaret fonksiyonun içinde erimiştir (Ylldrrım, 1996). Yine 17. yüzy1lda bölgede çıkan yangınların bölgedeki birçok ahşap binaya zarar vermesi sonucu, Galata'da yapılacak binalar taş ve kerpiç kullanılarak inşa edilmeye başlanmıştır. Zeynep Çelik, İstanbul'un ahşap konut dokusunun kent tarihi boyunca tehlike oluşturduğuna, 17. ve 19. yüzyıllar arasında İstanbul'da 109 büyük yangın meydana geldiğine, 19. yüzyılda bu sayının 229'a çıktığına ve kentin sürekli yangın tehlikesiyle yaşar hale geldiğine,

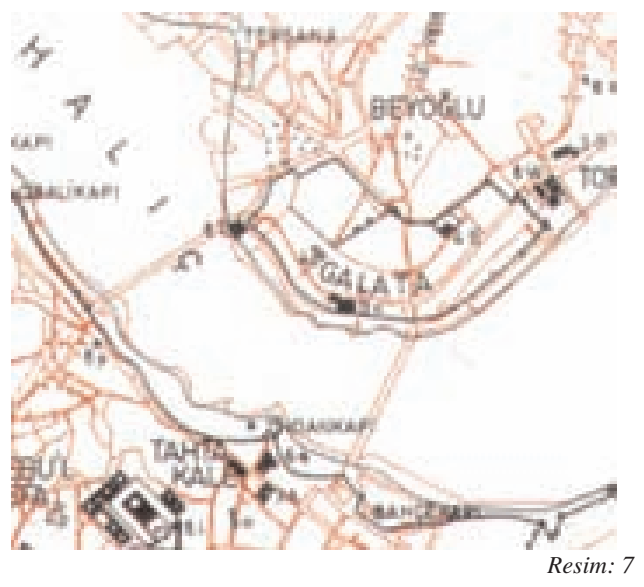

Resim: 7

15-17. Yüzyıllarda Galata (Müller-Wiener, 1998)

Resim: 8

Galata Surları şeması

(Biket, 2004)

1870 yılındaki büyük Pera yangınından sonra da kagir yapının zorunlu hale getirildiğine değinmiştir (Çelik, 1996). $\mathrm{Bu}$ da bize bölgedeki yapı karakterini açıklamaktadır (Resim: 7).

18. yüzyıl Osmanlı için bir batılılaşma hareketinin de yaşadığı bir geçiş dönemidir. "Galata'nın kentsel görünüşü İstanbul yarımadasından çok farklıdır. 15. yüzyıl surlarıyla kuşatılmış olan Galata, kalabalık bir nüfusu barındırmaktadır. 2800 metre uzunluğunda ve iki metre kalınlığındaki surlar, birbirini izleyen beş dönemde yapılmış ve Galata'yı 37 hektarı kaplayan beş bölgeye ayırmaktadır (Eyice 1969, 12) (Resim 8).

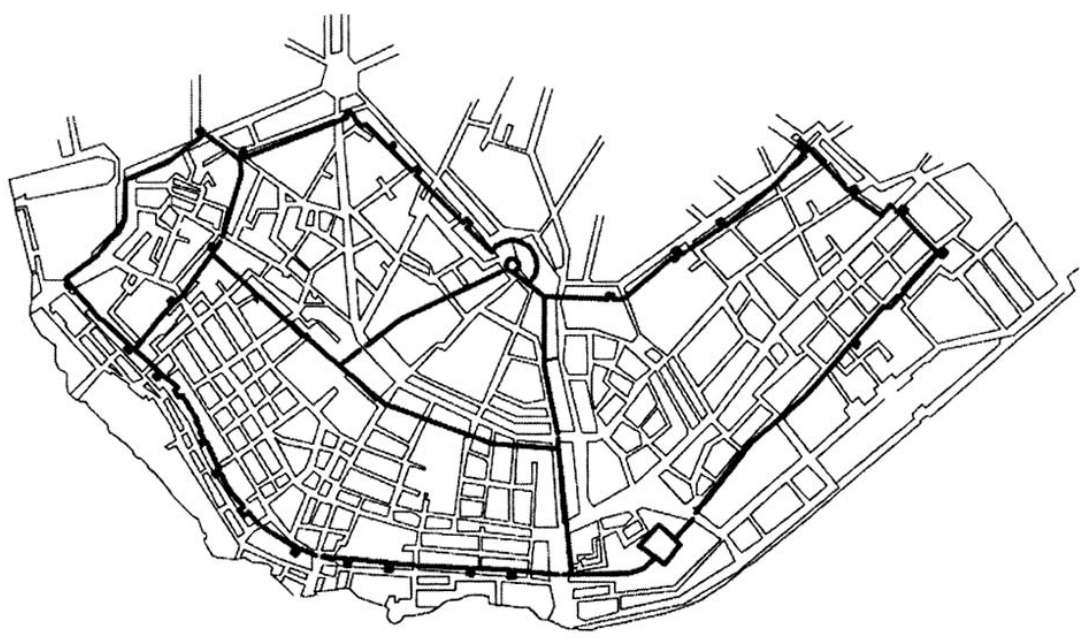

Resim: 8 
I Bu etnik gruplar rihtımin doğusunda kent surlarının ışında yaşarlardı.
19. yüzyılın ilk yarısında Galata Ermeniler, Rumlar, Frenkler ve Yahudilerden ${ }^{(I)}$ oluşan kozmopolit bir nüfusa sahiptir. Galata'nın yüzyıllar boyunca biçimlenmiş sıkı sokak ağı, kavis çizen kıyı şeridine paralel uzanan, merkezden açılan bir dizi yarım daire ve bunları sahilden yukarı semtlere düzensiz biçimde bağlayan geçitlerden oluşmuştur.

Ana cadde olmamakla birlikte bazı sokaklar (Voyvoda Cad., Galata Cad. Yüksek Kaldırım Cad. vb.) diğerlerinden daha önemli konumdadır (Çelik 1996, 36-40). 19. yüzyılda Avrupa ile yapılan ticaretin artması, bölgede bankacılık hizmetine ihtiyacı ortaya çıkarmıştır. Karaköy'ün etkin bir ticaret merkezi olması ve Beyoğlu'ndaki konut bölgeleriyle ilişkilerin yoğunlaşması Avrupa'nın ilk metrolarından birinin burada yapılmasını ve bu iki bölgeyi birbirine bağlamasını gerektirmiştir.

"Uluslararası ticaretle ilişkileri olan bankaların, düzenlenen Rıhtım Caddesi ile Karaköy'de odaklaşması, neo-klasik

Resim: 9

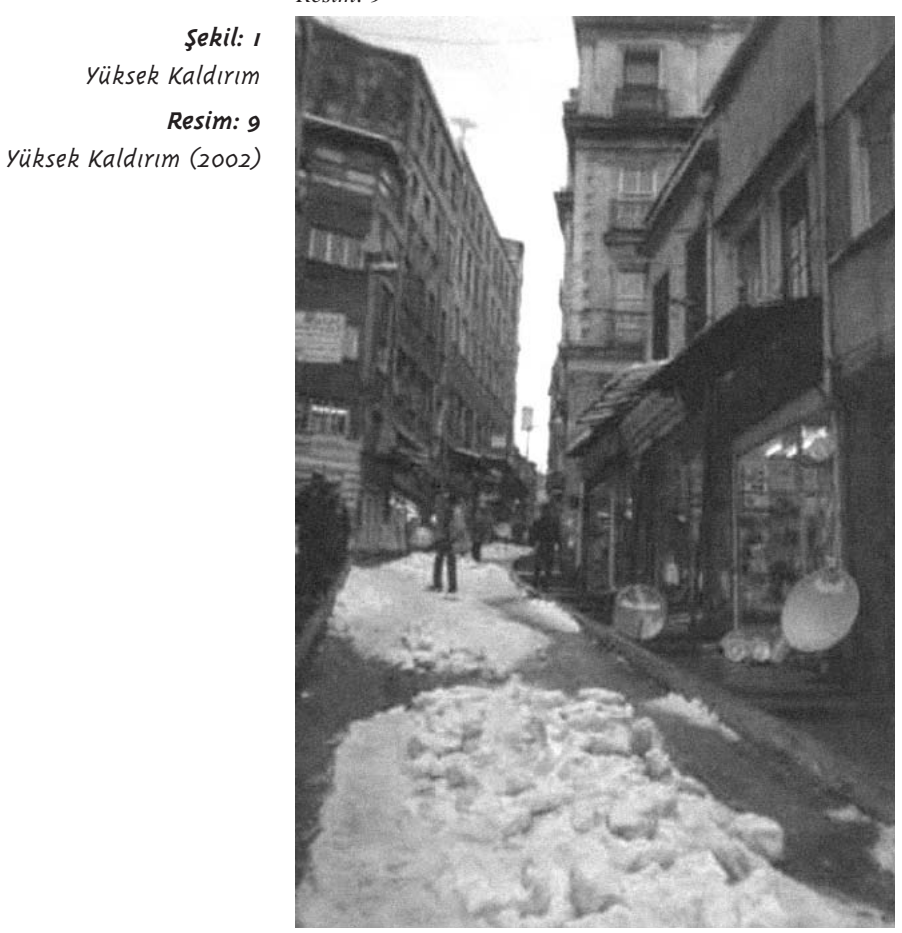

üslupta yeni taş binaların, iş hanlarının, sigorta şirketlerinin, gümrük binalarının, depo ve antrepoların da bu bölgede çoğalmasına neden olmuştur." (Yıldırım 1996, 32)

Bölgede ticari yapıların yanı sıra, Cenevizlilerden beri farklı dinlere sahip insan topluluklarının yaşamasının doğal bir sonucu olarak, kiliseler, manastırlar, sinagoglar; Müslümanlar'ın da yerleşmesiyle birlikte yapılan cami, mescit, çeşme, han ve hamamlar bulunmaktadır. Bunlar harita üzerinde işaretlediğinde hangi insan topluluklarının hangi bölgelerde yoğunlaştıkları görülebilir. Yıllar boyunca bu büyük çeşitlilik, bölgede birbirinin içine girerek günümüze kadar varlığını sürdürmüştür.

\section{Yüksek Kaldırım}

Yüksek Kaldırım "Karaköy Caddesi ile Voyvoda ve Kemeraltı caddelerinin birleştiği noktadan kuzeye, Galata Kulesi civarından geçerek Tünel Meydanına doğru çıkan yol ve bu güzergah çevresinde gelişmiş semt" olarak tanımlanmaktadır (Istanbul Ansiklopedisi, 1992) (Resim 9).

\subsection{Yüksek Kaldırım'ın Fiziksel Özellikleri}

Eski ev sahipleri Cenevizlilerin de etkisiyle denize dik inen yamaçlar üzerine kurulu İtalyan kentlerinin dik yokuşlu sokaklarının tüm özelliklerini taşır. Bu sokaklar çoğunlukla merdivenli, yer yer dirsekler çizerek, ya da düz bir çizgi boyunca ilerleyerek tepeye tırmanan sokaklardır. Yüksek Kaldırım da bu özelliğini merdivenli haliyle 1950'lere kadar koruyabilmiş nadir örneklerden biridir. 1956'da motorlu araç geçişine olanak tanınabilmesi için merdivenler kaldırılmış, iki arabanın yan yana zar zor geçebileceği kadar dar, bir o kadar da insan trafiği açısından yoğun bir sokak 
haline gelmiştir. Bugün ise düzensiz, özelliklerini yitirmiş sıradan bir yokuş olduğu söylenebilir (Resim 10).

\subsection{Yüksek Kaldırım'ı Anlatanlar}

Şermin Sarıbaş, Hürriyet Gazetesinde

1 Haziran 2001 tarihinde yayınlanan yazısında Yüksek Kaldırım'ı şöyle anlatmaktadır: "Karaköy'den Galata Mevlevîhânesi'ne, yani şimdiki Tünel Meydanı'na çıkan merdivenli yola "Yüksek Kaldırım” denilirdi. (...) Merdivenler ağır ağır çıkılır, köprübaşından kalkan vapurlara yetişebilmek için ise hızlı hızlı inilirdi. (...) 1860'larda Karaköy'den Beyoğlu'na oflaya puflaya tırmanan bir Fransız turist, açılacak bir tünel ile bu yorucu yokuşun ortadan kalkacağını düşündü. Fransa'ya dönünce bu fikrini, Henry Gawan adındaki mühendis arkadaşına açtı. Gawan bu fikri benimseyip İstanbul'a geldi ve günlerce yokuşta ter döken insanları sayıp, yapılacak bir tünelin çok kârlı olacağına karar verdi. Projesine destek bir İngiliz firmasından geldi. 'The Metropolitan Railway of Constantinople from Galata-Pera' adıyla başlayan tünel çalışmaları 1875'te tamamlandı. Böylece Londra'dan sonra dünyanın ikinci metrosu olan Tünel çalışmaya başladı."

Sermet Muhtar Alus "İstanbul Kazan Ben Kepçe” isimli kitabında Yüksek Kaldırım Caddesi'nin o günkü durumunun bir elli yıl öncesinden hiç farkı olmadığını anlatır. Tünelin "diri diri toprağa girme" ve "zelzele" endişelileri tarafından kullanılmadığını, bazı insanların da Tünelin ikinci mevkiine "yirmi parayı" feda edemediklerini, Beyoğlu'na çıkmak için Yüksek Kaldırım Caddesinin yoğunluğunu elli yıl önceki gibi devam ettirdiklerini anlatır. Sokağın Karaköy ucundan girerek yukarı çıkarken esnafından, dar cepheli şapkacıdan,
"Beyoğlu yosmalarının fotoğraflarını ecnebi seyyahlara sata sata para kıran" bir resim çerçevecisinden, resim malzemesi satan dükkanlardan, Çardaklı Kahve'den, sinemadan bahseder. Yine hemen hemen aynı yıllarda orada yürürmüş gibi Yüksek Kaldırım'ı ismini sokağın adından alan hikayesine konu eden, ancak sokağa Beyoğlu ucundan girerek anlatmaya başlayan bir başka yazar da Sait Faik Abasıyanık'tır. Münir Nurettin'den Tino Rossi'ye, Safiye Ayla'dan Bing Crosby'e ve Hafız Burhan'a kadar her telden müzik eşliğinde Galata'ya yürüdüğünü anlatır. Bir kahvede gösteriler yaptırılan bir fok balığını ve sahibini hikayesine konu eder. Yüksek Kaldırım'daki insan çeşitliliğinden bahseder (Öykülerde İstanbul, 2000) (Resim 11).
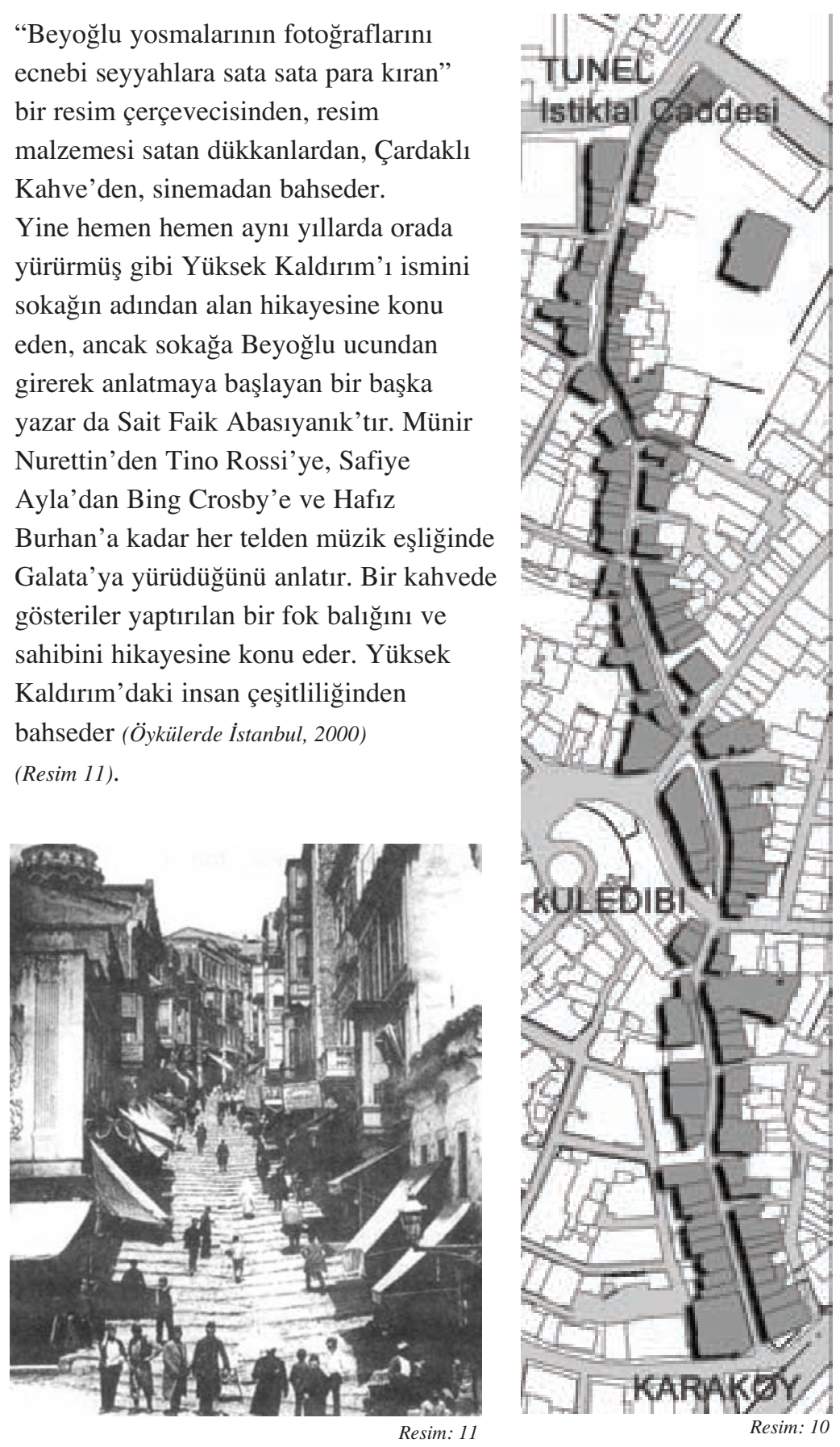

Murat Belge, İstanbul Gezi Rehberi isimli kitabında Yüksek Kaldırım'ın geçmişine ve günümüzdeki durumuna dair bilgiler vermektedir: "Burası eskiden basamaklı bir sokaktı ve şimdikinden çok daha güzeldi. İki yanındaki birçok ilginç dükkan veya başka iş yerleri de bu 
2 Dükkanin sahibi yazarın

kitabinin yayımlanmasindan

kısa bir süre sonra vefat

ettiğinden Çerkezo

kapanmıştır.

Günümüzde ise el

değistirmis ve yerine yine

ceuresindeki dükkanlar gibi

elektronik eşyaların satıldı̊̆ı

bir dükkan açılmıştır. güzelliğine katkıda bulunurdu eski plak satıcıları, İstanbul Gazetesi, dansingler, eski kitapçılar vb. Eski kitapçılardan biri, bazı pulcular, müzik aletleri satanlar kaldı, öbürleri yokuşun bu başındaki radyocu teypçilere ya da daha yukarılarda başlayan tahta kaplamacılara yerlerini bırakıp gittiler. İstanbul'un en iyi mezecilerinden biri- Bulgarların işlettiği- Çerkezo da bu

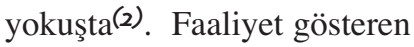
sinagoglardan biri de öyle, Çerkezo'nun karşı sırasında. Avusturya kökenli Aşkenazların 1900'de yaptırdığı bu sinagogun mimarının Tedeschi olduğu söylenir, ama başka iddialar da vardır. Şehirdeki kullanılan tek Aşkenaz sinagogudur. Tuhaf bir rastlantı sonucu onun da hemen arkası genelevlerin olduğu sokağa bakar; kutsal ve sefih yan yana." (Belge 1999, 132) (Resim 12).

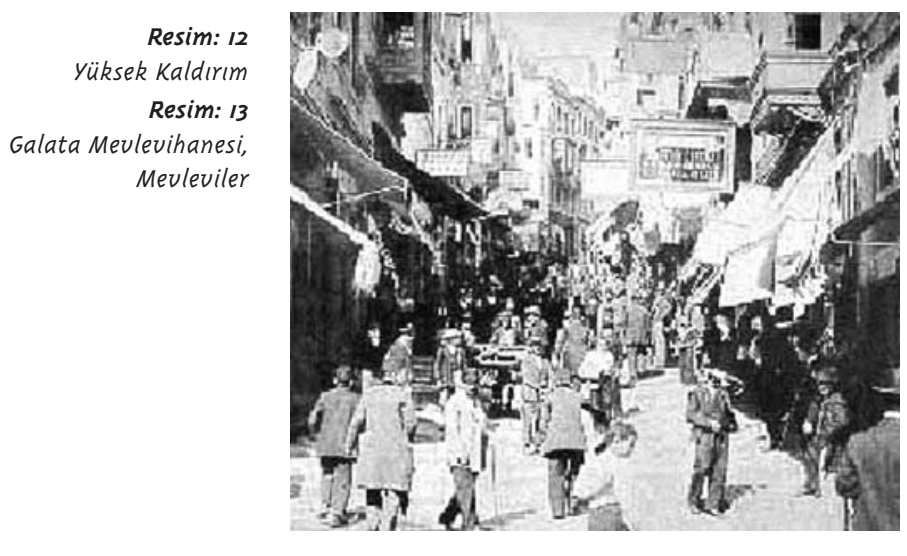

Resim: 12

\subsection{Yüksek Kaldırım'ın Sosyal Yapısı}

Yüksek Kaldırım'ın kentsel işlevlerini, bütün bu çevrede olduğu gibi Bizans döneminden itibaren Galata Limanı ve bölgesi belirlemiştir. Bu cadde, limanı Galata Kulesi ve Pera'ya bağlayan ana ulaşım bağlantısı olması nedeniyle önemli bir ticari işleve de sahiptir. Ticaret her şeyi, hatta tarihte tüm liman bölgelerinde olduğu gibi içki ve kadın ticaretini de kapsamaktadır. Zamanla (tünel gibi) yeni ulaşım yollarının açılması ve ulaşım ağının kayması nedenleriyle Yüksek Kaldırım'ın bu yoğun ticaret işlevi gerilemiştir. Cadde'nin yan sokaklarında ise genelevler etkinliklerine devam etmektedirler. 1879'da Yüksek Kaldırım'da bir konakta açılan Nisa Hastanesi de bölgenin bu özelliğine bağlı olarak genelevlerde çalışan kadınların sağlık kontrolünün yapılması amacıyla kurulmuştur (Belge 1999, 132).

Yüksek Kaldırım'ın iki yanında yol boyunca dükkanlar atölyeler, işyerleri dizilmiştir. Yüksek Kaldırım’ın Karaköy ucunda elektronik eşya satan dükkanlarla başlayan iş yerleri, Galata Kulesine doğru

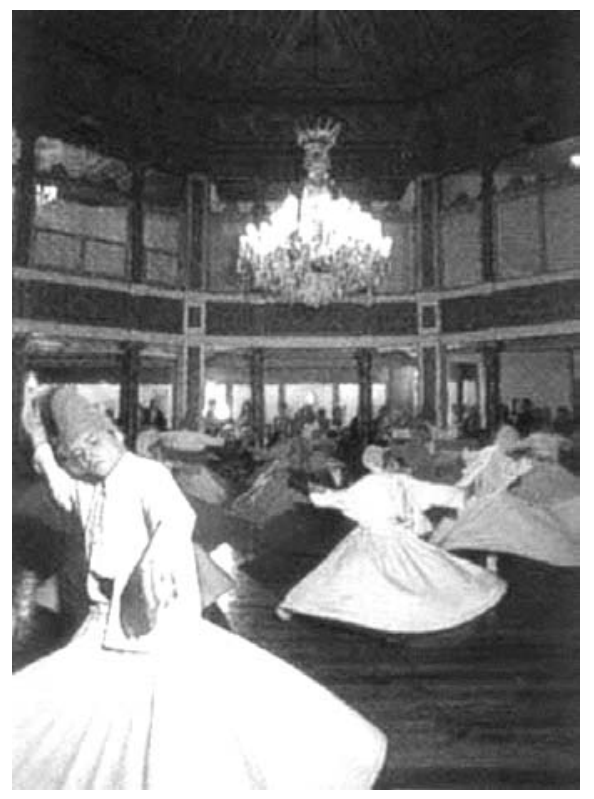

Resim: 13

reklam panosu yapan dükkanlar ve tahta kaplamacılarla, yeni ismiyle Galip Dede Caddesi'nin neredeyse tamaminda ise müzik aletleri satan dükkanlarla devam etmektedir. Burada müzik aletlerinin yanı sıra amatör ve profesyonel müzisyenlerin yararlandığı müzik ve kayıt stüdyoları da bulunmaktadır. Kuledibinde eskiden beri bulunan bitpazarı, eski eşya ve antikacıların uzantısı sayılabilecek birkaç dükkan görülmektedir (İstanbul Ansiklopedisi, 1992) (Resim 13). 


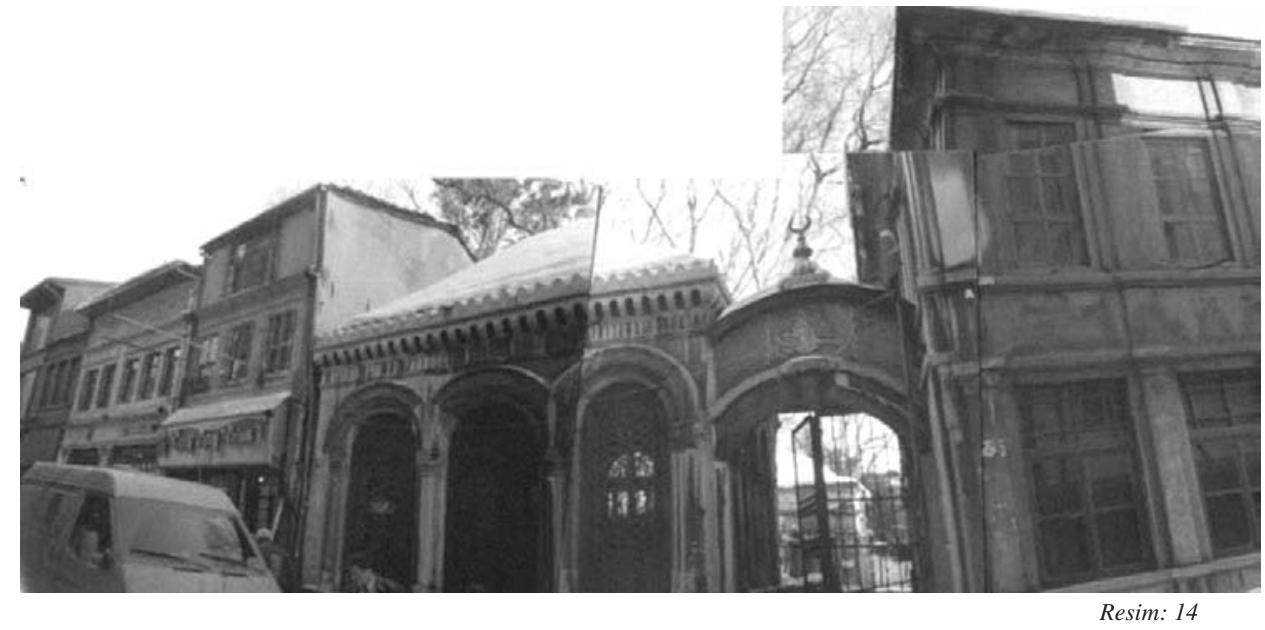

Fazla Müslüman'ın yaşamadığı bir bölgede yapılmış olan Mevlevi Tekkesi, Galip Dede Caddesi'nin Tünel ucunda bulunmaktadır. Murat Belge, İstanbul Gezi Rehberi isimli kitabında Mevlevihane ve onun tarihine de değinmiştir: "Mevlevi Tekkesinin fazla Müslüman olmayan bir yerde yapılmasına şaşmamalı. Mevleviler, sofu Müslüman halkın uzağında bulunmayı tercih etmişlerdir. Başlıca tekkeleri Yenikapı'da sur dışında, Beşiktaş’ta Eyüp

Bahariye'deydi. (...) Mevlevihane girişinde solda, Osmanlı tarihinin en entrikacı devlet adamlarından Halet Efendi'nin türbesi, sağında da muvakkithane ve kütüphanesi var. II. Mahmut uzun süre, kendisi dizginleri iyice ele alacak ve Yeniçeri Ocağına savaş açacak kadar güçlenmeyi beklemiş, bu süre içinde Halet Efendi'nin çevirdiği dolaplara katlanmak zorunda kalmıştı. İki "sonradan olma" Osmanlı, Humbaracı Ahmet Paşa ile İbrahim Müteferrika'nın mezarları birbirine komşu. Mezarlıktaki çeşitli Mevlevi dedelerinin en önemlileri Divan şiirinin son büyük üstadı Şeyh Galip ile Nayi Osman Dede.”

(Belge 1999, 128).

1492'de inşa edilen Mevlevihane, şehrin en eski tekkesidir. 19. yüzyılın sonlarında İstanbul'u ziyaret eden Hans Christian
Andersen ve ondan bir 50 yıl kadar sonra kente gelen Knut Hamsun'un, İstanbul'da iki İskandinav Seyyah isimli kitapta yer aldığ 1 gibi, neredeyse ilk ziyaret ettikleri yerlerden biri de mevlevihane olmuştur(3). $\mathrm{Bu}$ gün turistlerin ilgi odağ Mevlevihane Divan Edebiyatı Müzesi olarak canlılığını korumaktadır (Resim 14).

\section{Sonuç}

\section{Yüksek Kaldırım'ın Bugünü}

Yüksek Kaldırım Caddesi bugün eski yıllardaki birincil ticaret ve bir ana bağlantı noktası olma özelliğini çağın gelişmeleri, konut ve ticaret bölgelerinin

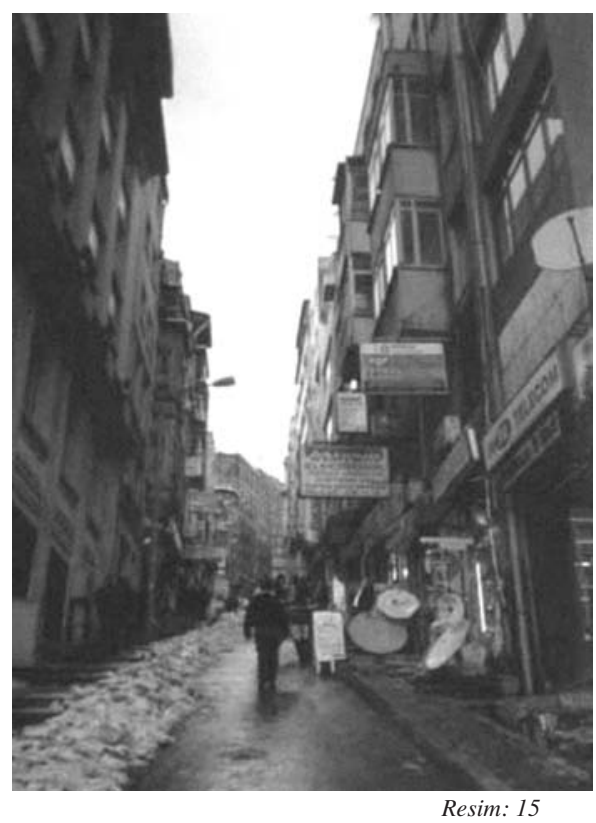

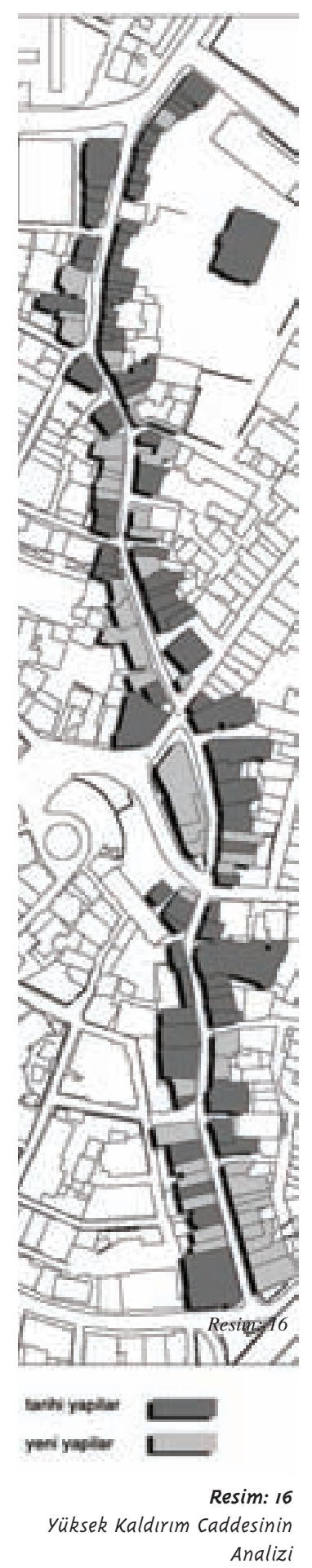

\footnotetext{
3 Gezginlerin ziyaret ettiği dönemde de bugünkü gibi tekkeye giriște kendilerinden para alındığindan, Mevlevilerin bir gösteri yaptıklarindan bahsetmektedirler.
} 


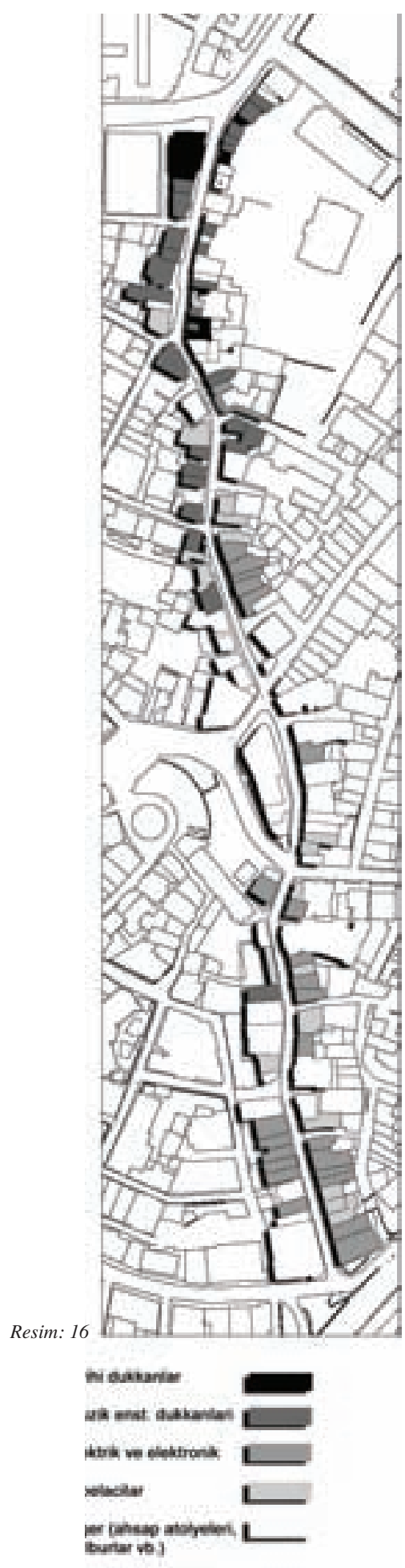

birbirinden ayrılması, İstanbul'un ana ticaret fonksiyonun başka noktalara kayması gibi nedenler sebebiyle kaybetmiştir. Birçok tarihi bina sadece zemin katları iş yeri olarak kullanılan, üst katları da depo olarak değerlendirilen harabeler haline gelmiştir. Zemin katların dükkan olarak kullanılması eğilimi de yine yapılarda hasarlara ve yapının özgünlüğünü kaybetmesine neden olmaktadır. Birçok bina koruma adı altında sadece boyanmakta bakımı gerektiği biçimde yapılamamaktadır. Bu durum da ne yazık ki cadde üzerindeki yapıların ve yapıların arasında kalan kentsel mekanın zaman içinde kendi kaderine bırakılmasına neden olmaktadır. Bugün Cadde üzerindeki yaklaşık yüz otuz adet binadan toplam on dört adedi kepenklerini indirmiş, üst katları yıkıntı halindedir. Bunun sebebi hem caddenin eski yüzünü yavaş yavaş yitirmeye başlaması, hem de ekonomik sıkıntılarla fiziksel eskimenin önüne geçilememesi biraz da yapıların mekansal anlamda çağdaş ihtiyaçlara cevap verememesidir. Sadece Yüksek Kaldırım Caddesi'nde değil hemen hemen tüm Galata'daki durum budur. Bir yerleşim bölgesi olma özelliğini yitirmekte olan bölge, gündüz insan trafiğgi ile müthiş bir kalabalığa cevap verirken gece tüm iş yerleri kapandıktan sonra iyice ıssızlaşmakta, 1ssızlık birçok başka faaliyeti beraberinde getirmekte, bu karanlık faaliyetler de bölgede yaşayan insanların kaçmasına Galata'nın geceleri yaşamayan, yaşamaktan korkulan bir bölge haline gelmesine neden olmaktadır. Bu kısır döngü gün geçtikçe Galata'yı o eski zamanlarında anlatılan nezih yüzünden, kültür merkezi olma niteliğinden sıyırmaktadır 1

\section{KAYNAKÇA}

Nur Akın, Nur. 1998. 19. Yüzyllın Íkinci Yarısında Galata ve Pera, Literatür Yayıncılık

Alus, Sermet Muhtar. 1997. İstanbul Kazan Ben Kepçe, İletişim Yayınları

Arkan, Özdemir Kaptan. 1998. Beyoğlu, Kısa Geçmişi, Argosu, İletișim Yayınları

Murat Belge, Murat. 1999. İstanbul Gezi Rehberi, Tarih Vakfi Yurt Yayınları

Berk, İlhan. 1985. Galata, Adam Yayınları

Biket, Aslı Pınar. 2004. Tarihi Kentlerde Yapılan Mimari ve Kentsel Tasarımda Kentsel Hafızanın Yeri ve Galata Örneği, Yıldız Teknik Üniversitesi, Yüksek Lisans Tezi

Zeynep Çelik, Zeynep. 1996. 19. Yüzyılda Osmanlı Başkenti, Değişen İstanbul, Tarih Vakfı Yurt Yayınları

Eyice, Semavi. 1994. Galata, Dünden Bugüne İstanbul Ansiklopedisi, Cilt 3, Kültür Bakanlığı ve Tarih Vakfı Yayınları

Eyice, Semavi. 1994. Galata Kulesi, Dünden Bugüne İstanbul Ansiklopedisi, Cilt 3, Kültür Bakanlığı ve Tarih Vakfı Yayınları

Eyice, Semavi. 1969. Galata ve Kulesi, Türkiye Turing ve Otomobil Kurumu

Eyice, Semavi. 1997. Görsel Gezi Rehberleri, İstanbul, Dost Yayınevi

Hamsun, Knut. ve Andersen, Hans. 1998. Ístanbul'da İki Iskandinav Seyyah, Yap1 Kredi Yayınları

http://www.ibb.gov.tr/ibbtr/140/14002/arsiv/bulten89/bir.htm

Kuban, Doğan. 1996. İstanbul Bir Kent Tarihi, Tarih Vakfı Yurt Yayınları

Müller-Wiener, Wolfgang. 1998. İstanbul'un Tarihi Topografyası, Yapı Kredi Yayınları

Müller-Wiener, Wolfgang. 2000. Öykülerde Ístanbul, Türkiye İş Bankası Kültür Yayınları

Sarıbaş, Ş. 2001. Tünel Canland, Haber

http://arsiv.hurriyetim.com.tr/tatilpazar/turk/01/01/06/ eklhab/81ekl.htm, 2006

Sişman, Deniz. 1998. Eski Kent Dokusunda Yeni Tasarım Kriterlerinin İrdelenmesi, Yıldız Teknik Üniversitesi, Yüksek Lisans Tezi

Yıldırım, Hüseyin. 1996. Tarihi Kent Dokularının Çağdaş Koruma İle Canlandırılması ve Yeni Yapı Tasarımları, Galata Suriçi Bölgesi Üzerine Bir Araştırma, Yıldız Teknik Üniversitesi, Yüksek Lisans Tezi 